\title{
HUBUNGAN PERILAKU ASERTIF DENGAN KENAKALAN REMAJA PADA SISWA SMP NEGERI 6 KOTA TEBING TINGGI
}

\author{
Marlise Butar Butar \\ Surel : marlisebutarbutar22@gmail.com
}

\begin{abstract}
ABSTRAK
Penelitian ini bertujuan untuk mengetahui hubungan perilaku asertif dengan kenakalan remaja pada siswa SMP Negeri 6 Tebing Tinggi. Rancangan penelitian yang digunakan adalah deskriptif dan korelasional. Sampel penelitian sejumlah 119 orang siswa, diambil dengan menggunakan teknik random sampling. Instrumen penelitian yang digunakan adalah skala psikologi. Teknik analisis data yang digunakan adalah analisis deskriptif dan analisis korelasi product moment. Berdasarkan penelitian diketahui bahwa sebagian besar perilaku asertif responden termasuk kategori tinggi yaitu 73,95\%. Sebagian besar kenakalan remaja responden yang termasuk dalam kategori cukup $64,71 \%$. Hasil analisis korelasi diperoleh besarnya koefisien korelasi sebesar 0,211 . Hasil uji korelasi menunjukkan bahwa rxy yang diperoleh sebesar -0,211 sedangkan pada $r$ tabel dengan $N=119$ sebesar 0,176 . Karena nilai $r$ hitung $>r$ tabel $(-0,211>0,176)$ maka terdapat hubungan negatif antara perilaku sertif dengan kenakalan remaja. Sumbangan efektif variabel asertif sebesar 4,45\% terhadap kenakalan remaja pada siswa Kelas VIII SMP Negeri 6 Tebing Tinggi.
\end{abstract}

Kata Kunci: Perilaku Asertif, Kenakalan Remaja

\section{PENDAHULUAN}

Anak adalah tunas bangsa yang akan tumbuh dan berkembang menjadi generasi penerus. Kewajiban kita mengantarkan mereka sehingga mampu mengembangkan kepribadian, menemukan identitas dirinya seirama dengan pertambahan usianya. Masa depan bangsa dan negara menjadi tanggung jawab dan terletak dipundak generasi muda. Generasi muda dapat dikatakan mempunyai posisi yang strategis.Remaja merupakan suatu generasi yang sangat penting dalam suatu negara, namun pada kenyataannya kenakalan remaja justru malah menjadi suatu permasalahan yang sangat besar bagi negara. Jaman modern seperti sekarang ini remaja lebih banyak menghabiskan waktu untuk melakukan hal-hal negatif dan menjurus pada penyimpangan tingkah laku dalam pertumbuhan dan perkembangannya, yang lazim disebut kenakalan remaja.

Sehubungan dengan berbagai peristiwa atau kejadian yang dialami manusia, tidak akan terlepas dari hubungan antar pribadi dengan orang lain, baik dengan orang-orang yang berada dalam lingkungan keluarganya, tetangga, maupun dengan teman, dan masyarakat. Menurut Hovland, dkk (1953) dalam Rakhmat (2001:3) komunikasi adalah proses dimana seorang individu (komunikator) mentransfer stimulasi (biasanya dalam bentuk verbal) untuk memodifikasi tingkah laku dari individu lain (penonton). Tokoh lain yang mendefinisikan komunikasi adalah Ross (1974) 
dalam Rakhmad (2001:3) bahwa komunikasi adalah proses transaksional yang meliputi pemisahan, pemilahan bersama lambang secara kognitif, begitu rupa sehingga membantu orang lain untuk mengeluarkannya dari pengalamannya sendiri atau respon yang sama dengan yang dimaksud oleh sumber.

Komunikasi adalah setiap bentuk tingkah laku seseorang, baik berupa verbal dan non verbal yang ditanggapi oleh orang lain. Setiap bentuk tingkah laku mengungkapkan pesan tertentu, sehingga juga merupakan bentuk komunikasi. Tingkah laku verbal adalah tingkah laku dengan menggunakan kata-kata sedangkan non verbal adalah tingkah laku dengan menggunakan isyarat. (Supratiknya, 1995:55). Penelitian ini berangkat dari fenomena perilaku remaja yang cenderung untuk ikutikutan. Bahkan untuk kenakalan yang mereka lakukan terkadang dilakukan hanya karena takut dianggap tidak gaul, dijauhi teman dan tekanan-tekanan lain dari teman sebaya. Beberapa penelitian menunjukkan bahwa remaja menjadi tidak mempunyai pendirian karena tekanan teman sebaya. Perubahan definisi sosial yang terjadi pada remaja turut pula membawa perubahan dalam bentuk hubungan dan perilaku interpersonal sehingga cenderung memunculkan pertanyaan dan masalah baru mengenai hubungan sosial. Akibatnya tidak sedikit remaja yang memiliki asertivitas rendah.
Fenomena yang ada menunjukan bahwa siswa Kelas VIII SMP kurang stabil dalam tingkat perkembangan emosionalnya karena usia mereka dapat dikategorikan memasuki rentang usia antara 13-15 tahun. Rentang usia itu termasuk dalam usia remaja. SMP Negeri 6 Tebing Tinggi khususnya terhadap siswa Kelas VIII yang sangat rentan sekali terhadap perubahan nilai-nilai sosial yang terjadi. Menurut informasi dari guru pembimbing, menunjukan 50\% siswa di Kelas VIII berpotensi nakal.

Kenakalan yang paling sering dilakukan oleh para siswa Kelas VIIISMP Negeri 6 diantaranya banyak siswa yang suka membolos sekolah atau sekedar santai di kantin untuk merokok. Mereka melakukan ini berawal karena ajakan teman. Anak-anak yang hanya ikut-ikutan, mereka tidak mampu mengutarakan pendapat mereka dengan baik karena takut menyinggung perasaan orang lain. Selain itu menurut sebagian siswa, mereka juga melakukan hal ini karena alasan solidaritas antar teman. Siswa yang membolos sekolah terjadi hampir setiap hari, kesempatan ini mereka gunakan untuk bermain play station, atau sekedar santai di warung dekat sekolah. Selama ini mereka lebih baik mengabaikan pendapat atau perasaan mereka daripada harus menghadapi konflik dengan orang lain. Mereka kurang mampu mengkomunikasikan keinginan dan perasaan dengan baik yang sekiranya tidak merugikan kedua belah pihak. 
Hal ini belum sesuai dengan apa yang dikatakan Muhammad (2003) dalam Ratna (2007:38) dengan berperilaku asertif keinginan, kebutuhan, dan perasaan individu untuk dimengerti oleh orang lain dapat tersalurkan. Dengan demikian tidak ada pihak yang tersakiti karena kedua belah pihak merasa dihargai dan di dengar, sekaligus keuntungan bagi individu sebab akan membuat individu di posisi sebagai pihak yang sering meminimalkan konflik atau perselisihan.

Kenakalan remaja yang terjadi pada siswa Kelas VIII SMP Negeri 6 lebih banyak disebabkan oleh pergaulan yang kaitannya dengan interaksi dan komunikasi antar teman sebaya baik itu di lingkungan teman satu kelas, satu sekolah ataupun antar kelas. Komunikasi antar teman sebaya sangat berpengaruh terhadap remaja dikarenakan dalam pergaulan antar teman yang perbedaan umurnya tidak terpaut jauh, remaja cenderung lebih suka meniru apa yang dilakukan oleh teman-temannya dengan alasan apabila tidak dilakukan maka mereka akan menjauhi. Orang tua juga sangat berperan penting dalam menjaga pergaulan anak-anaknya, kesibukan orang tua yang berlebihan biasanya menyebabkan anak cenderung terlalu bebas bergaul dengan siapa saja tanpa bisa membedakan mana yang baik dan buruk karena kurangnya perhatian dari orang tua, pola asuh yang terlalu protektif dan komunikasi yang tertutup dalam keluarga.
Banyak kasus yang terjadi akibat seseorang kurang memiliki perilaku asertif yang pada akhirnya akan merugikan diri sendiri. Fenomena yang marak terjadi misalnya saja pada anak yang terjerumus narkoba. Mereka melakukan hal di luar keinginan akibat tak berterus terang dengan pendapat yang dia miliki. Anak mudah terpengaruh dalam penggunaan narkoba karena ia takut dinilai sebagai remaja yang tidak bisa mengikuti perkembangan jaman. Begitu juga pada anak yang melakukan pergaulan bebas, dia takut menolak ajakan pasangan karena takut dinilai tidak benar-benar mencintai pasangan. Sikap asertif diharapkan anak akan lebih leluasa mengemukakan pendapat tanpa harus menyakiti perasaan orang lain dan bisa tetap mempertahankan hak pribadi. Hasil penelitian Daradjat (1985) dalam Uyun (2006:32) yang mengemukakan agar seseorang berperilaku baik tentu saja harus didasari adanya kemampuan untuk menyesuaiakan dirinya (asertif) dengan keadaan lingkungan tempat ia tinggal, sedangkan bila seseorang gagal dalam mengadakan penyesuaian diri akan dimanifestasi dalam kelainan tingkah laku yang dimunculkan dalam bentuk tingkah laku yang agresif, penganiayaan, penipuan, pemakaian obat terlarang atau narkotika dan sebagainya.

Berdasarkan uraian yang ada tampak bahwa ada keterkaitan antara perilaku asertif dengan kenakalan remaja. Meski demikian, penelitian 
mengenai hal tersebut belum banyak dilakukan. Sesuai dengan rumusan masalah yang telah diajukan, maka tujuan yang hendak dicapai dalam penelitian ini adalah : Mengetahui Hubungan perilaku asertif dengan kenakalan remaja Kelas VIII di SMP Negeri 6 Tebing Tinggi Tahun ajaran 2017.

\section{METODE PENELITIAN}

Pendekatan yang digunakan dalam penelitian ini adalah pendekatan kuantitatif. Menurut Arikunto (2002:10) mendefinisikan "penelitian kuantitatif merupakan suatu penelitian yang menggunakan angka dalam mengumpulkan data dan dalam memberikan penafsiran terhadap hasilnya". Jenis penelitian yang digunakan dalam penelitian ini adalah penelitian korelasi. Dalam penelitian korelasi bertujuan untuk menemukan ada tidaknya hubungan dan apabila ada berapa eratnya hubungan serta berarti ada tidaknya hubungan itu (Suharsimi Arikunto, 1997:239). Dalam penelitian ini bertujuan untuk menemukan hubungan antar variabel bebas yaitu Perilaku Asertif (X) dengan variabel terikat yaitu Kenakalan Remaja (Y).

Data merupakan hal yang utama dalam setiap penelitian karena merupakan objek yang diteliti. Untuk mendapatkan data yang diperlukan dengan menggunakan metode pengumpulan data. Penumpulan data merupakan proses kegiatan yang sangat penting dalam penelitian ilmiah karena akan digunakan untuk menguji hipotesis dan mengungkap fakta mengenai variabel yang diteliti dengan menggunakan metode yang tepat dan instrumen yang baku. Di dalam kegiatan penelitian, cara memperoleh data dikenal sebagai metode pengumpulan data (Arikunto, 2006:149). Metode pengumpulan data merupakan suatu cara yang ditempuh oleh peneliti untuk memperoleh data yang diteliti. Dalam penelitian ini, data yang dicari adalah tentang hubungan perilaku asertif dengan kenakalan remaja. Jadi metode pengumpulan data dalam penelitian ini berupa skala psikologi untuk mengungkap perilaku asertif dan kenakalan remaja. Skala psikologi adalah alat untuk mengukur aspek atau atribut afektif. (Saifuddin Azwar, 2000:3).

Alasan menggunakan skala psikologi sebagai alat ukur adalah: 1) penggunaan skala psikologi bersifat paktis, hemat waktu tenaga dan biaya, 2) Dapat digunakan untuk mengumpulkan data dari responden dalam jumlah banyak dalam waktu yang singkat, 3) Setiap responden menerima pernyataan yang sama, responden lebih leluasa dalam menjawab pertanyaan skala psikologi karena tidak dipengaruhi oleh sikap mental hubungan antara peneliti dengan responden, 4) Responden mempunyai waktu yang cukup untuk menjawab pertanyaan, dapat dibuat anonim sehingga responden bebas dan tidak malu-malu dalam menjawab, 5) Data yang telah terkumpul lebih mudah dianalisis sebab pertanyaan yang diajukan kepada setiap responden adalah 
sama. Ditegaskan juga oleh Azwar (2002: 3) “istilah skala psikologi selalu mengacu kepada alat ukur atau atribut efektif".

Skala psikologi dapat digunakan sebagai alat ukur yang dapat mengungkap indikator perilaku yang berupa pertanyaan maupun pernyataan tersebut. Dari hasil jawaban responden kemudian diinterpretasikan sesuai dengan sesuatu yang hendak diukur.

Analisis data dalam suatu penelitian ilmiah merupakan bagian yang sangat penting, karena dengan adanya analisis data masalah dalam penelitian tersebut dapat diketahui jawabannya. Analisis data merupakan salah satu cara untuk menjawab permasalahan dalam penelitian atau untuk menjawab hipotesis dalam peneilitian. Menurut Suharsimi Arikunto (1997:347) bahwa pengolahan data dapat dilakukan dengan dua cara yaitu non statistik dan cara statistik, yaitu menggunakan rumus statistik yang ada. Analisis data penelitian dilakukan melalui uji secara kuantitatif dengan menggunakan metode statistik. Pengolahan data dengan cara statistik adalah suatu cara pengolahan data dengan menggunakan angka.

\section{HASIL PENELITIAN DAN PEMBAHASAN}

Penelitian ini bertujuan untuk mengetahui gambaran perilaku asertif siswa Kelas VIII di SMP Negeri 6 Tebing Tinggi Tahun ajaran
2017, mengetahui gambaran kenakalan remaja Kelas VIII di SMP Negeri 6 Tebing Tinggi Tahun ajaran 2017 dan mengetahui hubungan perilaku asertif dengan kenakalan remaja Kelas VIII di SMP Negeri 6 Tebing Tinggi Tahun ajaran 2017. Penelitian merupakan suatu kegiatan ilmiah, oleh karena itu penelitian dilakukan secara berurutan, bertujuan dan sistematis. Agar penelitian berjalan sebagaimana yang ditentukan, tepat pada waktunya dan hasilnya dapat dipertanggungjawabkan maka diperlukan persiapan penelitian. Dalam bab 4 ini akan dipaparkan tentang hasil penelitian yang telah dilaksanakan, analisis data beserta pembahasannya.

Hasil penelitian menunjukan bahwa terdapat hubungan yang signifikan antara perilaku asertif dengan kenakalan remaja pada siswa Kelas VIII SMP Negeri 6 Tebing Tinggi tahun ajaran 2016/2017, dengan nilai $-0,211$ dan $\mathrm{r}$ tabel $=$ 0,176 . Hal ini menunjukan pola keterkaitan atau hubungan kedua variabel tersebut bersifat negatif, yang dapat diartikan apabila semakin tingkat asertivitas siswa, maka kenakalan remaja akan menurun, sebaliknya apabila tingkat asertivitas siswa mengalami penurunan, maka kenakalan remaja akan semakin meningkat. Dengan demikian dapat diperoleh gambaran bahwa semakin tinggi perilaku asertif yang dimiliki individu, maka semakin rendah kenakalan remaja.yang ditimbulkan oleh individu, bahwa orang-orang 
yang memiliki asertivitas yang rendah akan semakin mudah terbawa dalam pengaruh lingkungan sekitar yang negatif atau perilaku menyimpang. Hal ini senada dengan penelitian lain dalam hubungannya dengan sikap asertif menunjukan bahwa semakin tinggi kemampuan seseorang dalam bersikap asertif akan semakin tidak mudah terbawa dalam penyimpangan perilaku (Levinston, 1984:478). Sehingga dapat dikatakan Perilaku asertif erat kaitannya dengan kenakalan remaja.

Dapat disimpulkan bahwa apabila mahasiswa memiliki asertivitas tinggi, maka siswa akan mampu mengkomunikasikan kebutuhan, keinginan, perasaan atau opini kepada orang lain dengan cara langsung dan jujur tanpa bermaksud menyakiti perasaan siapapun. Pada umumnya orang yang asertif dalam kehidupannya sehari-hari, mampu mengenal dirinya sendiri dengan baik, sehingga mampu menentukan pilihan keinginan dan tujuan hidupnya tanpa haras mempengaruhi orang lain. Remaja dengan asertivitas tinggi mampu membela dirinya sendiri maupun orang lain ketika diperlakukan tidak adil, mampu memberikan tanggapan terhadap masalah yang dihadapi yang dapat mempengaruhi hidupnya, serta mampu menyatakan keinginannya secara tegas terhadap orang lain. Hal ini mendukung pendapat Rini (2001) dalam (Asia, 2008:5) asertivitas adalah perilaku yang menampakkan kemampuan untuk mengkomunikasikan apa yang diinginkan, dirasakan dan dipikirkan kepada orang lain namun dengan tetap menjaga dan menghargai hakhak serta perasaan pihak lain. Seseorang dikatakan mampu bersikap asertif jika dirinya mampu bersikap tulus dan jujur dalam mengekspresikan perasaan, pikiran dan pandangan pada pihak lain sehingga tidak merugikan atau mengancam integritas pihak lain.

Perilaku asertif adalah pengungkapan diri secara terbuka, tegas dan bebas atas perasaan positif dan negatif maupun tindakan mempertahankan hak mutlak dengan tetap memperhatikan perasaan orang lain. Dengan memiliki perilaku asertif maka anak akan mampu untuk mengungkapkan perasaannya tanpa menyakiti orang lain sehingga tidak menimbulkan perilaku menyimpang. Dengan kata lain, orang-orang yang memiliki sikap asertif yang tinggi akan lebih mampu menjaga dirinya, tidak melakukan perilaku menyimpang atau kenakalan remaja, karena dia mampu menghargai dirinya dan mampu mengendalikan dirinya dari pengaruh orang lain dengan mengatakan tidak untuk halhal yang tidak sesuai dengan nilainilai yang diyakininya.

Berdasarkan hasil penelitian menunjukan bahwa asertivitas pada siswa Kelas VIII SMP Negeri 6 Tebing Tinggi Tahun Ajaran 2017 berada pada kategori tinggi. Hasil analisis korelasi penelitian ini menunjukan sumbangan efektif variabel asertif sebesar 4,45\% terhadap kenakalan remaja pada 
siswa Kelas VIII SMP Negeri 6 Tebing Tinggi. Kondisi tersebut menunjukan bahwa tingkat konsistensi variabel kenakalan remaja sebesar $4,45 \%$ dapat diprediksi oleh asertivitas dan sisanya ditentukan oleh faktor-faktor lain yang tidak diungkap oleh penelitian ini. Dari analisis diatas maka dapat disimpulkan bahwa ada hubungan yang negatif antara perilaku asertif dengan kenakalan remaja pada siswa Kelas VIII SMP Negeri 6 Tebing Tinggi tahun ajaran 2016/2017.

\section{SIMPULAN}

Berdasarkan hasil penelitian dan pembahasan yang ada di bab 4 maka dapat diambil kesimpulan sebagai berikut:

a. Perilaku asertif siswa Kelas VIII di SMP Negeri 6 Tebing Tinggi Tahun ajaran 2017 termasuk dalam kategori tinggi

b. Kenakalan remaja Kelas VIII di SMP Negeri 6 Tebing Tinggi Tahun ajaran 2017 termasuk dalam kategori cukup.

c. Ada hubungan negatif antara perilaku asertif dengan kenakalan remaja pada siswa Kelas VIII SMP Negeri 6 Tebing Tinggi tahun ajaran 2016/2017”. Semakin tinggi perilaku asertif yang dimiliki individu, maka semakin rendah kenakalan remaja.yang ditimbulkan oleh individu.

\section{DAFTAR RUJUKAN}

Adam dan Lenz. 1995. Jadilah diri Anda Sendiri. Cetakan Pertama. Alih Bahasa Koentjara. Jakarta: Gramedia.

Ali, Muhammad. 1987. Penelitian Kependidikan Prosedur dan strategi. Bandung:Angkasa.

Arikunto, Suharsimi. 2006. Prosedur Penelitian Suatu Pendekatan Praktek. Jakarta: Rineka Cipta.

Asia. 2008. Hubungan antara harga diri dan asertivitas dengan perilaku prososial remaja. Skripsi (tidak diterbitkan) Surakarta: Universitas Muhammadiyah Surakarta.

Awaluddin. 2008. Assertive Behaviour on early teen. Psychology jurnal. Jakarta: Universitas Gunadarma.

Azwar, Saifudin. 2000. Skala Psikologi. Yogyakarta: Pustaka Pelajar.

Basri, Hasan. 1994. Remaja Berkualitas. $\quad$ Yogyakarta: Pustaka Pelajar.

Gunarsa, Singgih. 1981. Psikologi Remaja. Jakarta: Gunung Mulia.

Hadi. 1986. Metodologi penelitian Penelitian. Yogyakarta: Andi.

Kartono, Karitini. 1999. Patologi Sosial. Jakarta: Raja Grafindo Persada.

Mariana. 2002. Sikap Asertif Remaja Putri terhadap lawan jenis ditinjau dari sekolah yang berlandaskan keagamaan dan sekolah umum. Skripsi (tidak diterbitkan). Semarang: UNIKA Soegijapranata. 
Marlise Butar Butar : Hubungan Prilaku ...

Nashori, F. 2000. Hubungan antara Konsep Diri dengan Kompetensi Interpersonal Mahasiswa. Anima Surabaya: Universitas Surabaya. Vol. 16. No.1. (32-40)

Nazir, Moh. 2003. Metode penelitian. Jakarta: Ghalia Indonesia.

Lloyd, $\quad$ Sam $\quad$ R. 1990. Mengembangkan perilaku Asertif yang positif. Jakarta: Binarupa Aksara.

Liza. 2005. Perbedaan Asertivitas Remaja ditinjau dari Pola Asuh Orang Tua Psikologia. Sumatera: Universitas Sumatera. Vol. 1. No.2. (4652)

Levinston. 1984. Accesing Human Servicer. London: Sage Publication

Prabowo, Sumbodo. 2000. Membangun Perilaku Asertif pada Komunikasi antara perawat dan pasien. Psikodimensia. $\quad$ Semarang: Universitas Katholik Soegijapranata. Vol.1 No.1 (620). 